\title{
EVALUATION ON THE EFFECT OF SUSTAINABLE ENVIRONMENTAL FRIENDLY BIO-PESTICIDE ON THE GROWTH OF SEED BORNE FUNGI (ASPERGILLUS NIGER) ON COWPEA (VIGNA UNGUICULATA L. WALP.)
}

\author{
Azawei Alamene*, Okorodo Payebo Cameroun and Blessing Ebimie \\ Department of Crop and Soil Science, Faculty of Agriculture, Niger Delta University, \\ Wilberforce Island, Bayelsa State. \\ *Correspondence Email Address: alameneazawei@yahoo.co.uk
}

\section{Cite this article:}

Azawei A., Okorodo P.C., Blessing E. (2021), Evaluation on the Effect of Sustainable Environmental Friendly Biopesticide on the Growth of seed Borne Fungi (Aspergillus niger) on Cowpea (Vigna unguiculata L. Walp.). African Journal of Agriculture and Food Science 4(2), 55-79. DOI: $10.52589 / A J A F S-$ BUX3TPIE.

\section{Manuscript History \\ Received: 3 Feb 2021 \\ Accepted: 28 March 2021 \\ Published: 29 June 2021}

Copyright $\odot 2020$ The Author(s). This is an Open Access article distributed under the terms of Creative Commons AttributionNonCommercial-NoDerivatives 4.0 International (CC BY-NC-ND 4.0 ), which permits anyone to

share, use, reproduce and redistribute in any medium, provided the original author and source are credited.
ABSTRACT: Evaluation on the Effect of Sustainable Environmental Friendly Bio Pesticides Application on the Growth of Seed borne Fungi on Cowpea (Vigna unguiculata L. Walp.) was conducted at the Department of Crop and Soil Science Laboratory, Niger Delta University, Wilberforce Island, Bayelsa State, Nigeria. To determine the percentage (\%) efficacy of plant essential oils and to evaluate the best plant essential oil on the suppression of the pathogen cultured and treated Potatoes Dextrose Agar (PDA) plates with the different plant essential oils concentration levels $(0.1,0.01$, and $0.001 \%)$. This experiment was arranged in Complete Randomized Design (CRD) and each treatment was replicated three times and each replicate contained 12 petri dishes. The result shows that ginger oil at 0.1 in all the days of the bioassay assessment, particularly, from day 6-dayl0 proved more effective in suppressing the teste pathogen (A. niger), this could be the present of the active ingredient (Zingerone) on the treatment. Therefore, this result should be encouraged for Cowpea farmers as seed treatment before storage to prevent Cowpea weevils (Callosobruchus maculatus) as a grain storage insect pest, that causes serious destruction on the stored grains.

KEYWORD: Cowpea, CRD, PDA, Sustainable, Environmental, Friendly, Biopesticide 


\section{INTRODUCTION}

Cowpea (Vigna unguiculata L. Walp.) is an important food and animal feed crop grown in the semi-arid tropics covering the Africa continent, Asia, Europe, United States and Central and South America. It originated from USA and was domesticated in Southern Africa and was later moved to East and West Africa and Asia.

Cowpea is a leguminous seed that is widely produced in Africa continent under marginal production systems. Cowpeas performed well even when produced in marginal soils, due to their ability to fix substantial nitrogen in the soil as reported by (Hall. et al. 2003). Through improved breeding lines and agronomic practices, could be applied

However, there is potential for increased production of cowpeas despite the prevailing production challenges of declining soil fertility in the arable land such as; unreliable rainfall, pests and diseases incidence as presented by (Singh. et al. 2005).

Grains contained $25 \%$ protein, and several vitamins and minerals. The plant tolerates drought, and performed well in a wide variety of different soils types, and being a legume replenishes low fertility content of soils when the roots are left to decay in the soil where cowpea was propagated.

\section{Production of Cowpea in Nigeria}

Cowpea (Vigna unguiculata Walp) is a very important leguminous crop which is grown in different geographical regions of Nigeria. It provides protein requirement to final consumers as a substitute for the animal protein. However, cowpea production is generally low as a result of some factors such as diseases and insect pests, drought, and weeds as reported by Gungula and Garjila, 2005). There is a good development of cowpea production within the two decades which is attributable to the significant advancement made on cowpea seed improvement in the dry arable lands by the IITA. Although Nigeria is the largest producer of cowpea in the world, producing about $56 \%$ (percent) of the world production from the available research data, also from available data shows that Nigerians are the largest consumer of cowpea in the world, (NAQA, 2001), as a result of this substantial amounts of cowpea which came in to Nigeria from neighboring countries especially Cameroon and Chad. A large proportion of cowpea grains or seeds from Burkina Faso and Mali are sold into Côte d'Ivoire. (Lowemberg -DeBoer, J. et al., 2000) In Nigeria the organization of traders in Kano's Dawanau market - the largest cowpea market in the world - differs from other trading organizations. Traders are organized into a formal market unions or association, "Dawanau Market Development Association" comprised of smaller or micro associations such as Dawanau Farm Produce Merchant Association, Restaurant Owners Association, Transport Operator Associations, all the association geared towards rapid cowpea production for efficient storage of grains etc. The main role of the major association is to negotiate with the government over issues such as taxes and market infrastructure, or the purpose of promoting cowpea production (Langyintuo, et al., 2003).

Cowpea is a major food crop and is widely grown in Adamawa state, however, with increasing population over the years, the demand for the crop had gone up but the production has not been increased significantly to meet the people demand (Agwu, 2001). Because of this issue researches have evaluated the profitability and technical efficiency of production of the crop in 
Adamawa State Nigeria and also identifies the factors affecting the inefficiency in the production processes.

\section{Storage of Cowpea Grains}

Cowpea is one of the most economically and nutritionally important indigenous African grain legumes produced throughout the tropical and subtropical areas of the world, it is one of the most ancient crops known to man in the Bible, when Joseph became the Prime Minster at Egypt and Joseph was also known as the first great scientist on earth to preserve grains of crop with spices that led to other storage or preservative methods of grain storage. Due to its importance several researchers have developed different approaches for preservation of cowpea grains during storage to prevent insect pest infection, as illustrated below to preserve the cowpea grains shelf life for a longer period.

According to previous work (Bawa, et al. 2012) reported on the storage structures of cowpea, they used Clay pots to store grains of cowpea and mixed with wood ash, Neem leaf extracts with Storage containers such as Jute bags, Plastic containers, Hessian bags and Polythene bags and Zero fly bags. Other storage methods include barns on raised platforms using sticks and thatch for both the floor and roof (only cowpea in pod is stored with this method) and small containers using mud bricks for construction and using cement for plastering of the floor and walls, and of jute sacks. Cowpeas are particularly susceptible to damage in storage, mainly by cowpea bruchids (Callosobruchus maculatus) in order to prevent this storage weevil infection.

\section{Storage Method of Cowpea Grains}

Cowpea grains storage strategies was conducted for the purpose of; maintaining regular supply of the crop and its by-products throughout the year, Sale in times of scarcity at high prices to fetch more money, Preservation of seeds for planting at the next cropping seasons and it also encourages Price stabilization when Government buys surplus cowpea at the time of harvest at low prices and released them periodically in times of scarcity to force prices down and prevent inflation. There are alternative approaches of non-synthetic cost effect storage methods available to cowpea farmers, as illustrated below.

The use of botanical ashes to protect the grains from post-harvest losses caused by cowpea storage weevils which are highly significant and contributes significantly to the uniqueness and success of this system (GIAHS Programme, 2006). Good grain storage prevents grain losses and maintains grain quality. One of the most effective means of achieving this is the use of fumigation or controlled atmospheric storage. These techniques work by holding grains in a gas-tight enclosure in a gaseous atmosphere that could kill insect pests or limit agents of bio deterioration as reported by (Dramani, 2010).

According to Dramani, (2010), control of cowpea storage pests and diseases can be achieved by: good storage structures, effective conventional insecticides and good plant materials. The following structures were recommended by Ali, (2008), for cowpea storage: Earthen wave Granaries (Rumbus), Steel Drums/Tins, Polythene bags, Silos, Pit method, Earthen wave, Grass rhuubus and Mud rhumbus

When grains are already infested by insect pests, it often becomes necessary to apply insecticides for their control. The recommended insecticides by Ali, (2008), for storage of cowpea include: Actellic 25 E.C, Actellic 2\% dust, Phostoxin tablet and Actellic 25 EC. All 
these approaches are not environmental friendly, hence the alternative strategies of non chemical that is botanicals were currently researched upon

\section{Importance of Cowpea}

Cowpea (Vigna unguiculata), the grouping of cowpea as a leafy vegetable was evaluated by researchers from different African countries because of its significant role it played. This was based on a comprehensive survey conducted from four African countries, namely Malawi, Uganda, Rwanda and Tanzania (Keller 2004; Weinberger and Msuya 2004) in a collaborative project research conducted for the 'Promotion of Neglected Indigenous Vegetable crops for Nutritional Health improvement in Eastern and Southern Africa' (ProNIVA). Cowpea is an important food legume crop, and its use as a leafy vegetable is essential in many African countries as been evaluated.

However, despite its regional importance, cowpea's use as leafy vegetable in many African countries has been widely neglected in research and improvement programs before (Barrett 1990; Schippers 2002), and it can, therefore, be considered as a neglected crop before. Although lately, some research has been carried out on African indigenous vegetables, especially leafy ones, cowpea research continued to focus on improvements of the grain and/or the entire herbage for both human food and animal feed (Singh et al. 2003). Yet it is the leaves of some legumes, like cowpea, that show much promising effect for producing part of the vastly increased supplies of nutrients that the world population, is presently in higher demand of the cropto meet up the protein requirement of plants. Therefore, the need remains to further intensively research and promote leafy vegetables and their benefits to showcase the importance of leafy vegetable usage. Hence, the ProNIVA project was launched by the World Vegetable Center (AVRDC) and partners, for the promotion of cowpea production in the African region and the entire Global World.

In West Africa, cowpeas are one of the major sources of proteins in a carbohydrate based dietary food (Uwaegbute, et al. 2000), where they are consumed in different forms. Whole cowpeas are consumed after being stewed, while different products based on a wet milled paste such as akara and moimoi are also produced. Apart from the traditional products, cowpeas are also being processed into flour for the production of bakery products such as cookies and breads (Kethireddpalli, et al., 2005), as well as comminuted meat products such as chicken nuggets (Prinyawiwatkul et al., 1997b) and meat balls (Serdaroglu et al., 2005).

\section{Insect Pest and Diseases of Stored Cowpea Grains}

The production and storage of cowpea was hindered by an array of insect pests and disease occurence which affected yield, quality, nutritional value and viability negatively, due lack of adequate storage and transport facilities have led to severe postharvest losses experienced in developing countries (Sharma et al., 2009), thus, making the environment more conducive for the growth of storage fungi. Furthermore, most of these fungi produced toxic metabolites, called mycotoxins, which constituted health problems to humans, animals and plants (Reverberi, et al., 2010). Various synthetic fungicides were evaluated on cowpea, which have some adverse effects such as toxic residue, development of resistant strains, high cost and toxicity to mammals, because some of them contained heavy metals (Azher, 2009).

The major insect pests of stored cowpea in tropical Africa include: Callosobruchus maculatus (Fab.) and Bruchidius atrolineatus (Pic), with the former the most prevalent. C. maculatus 
attack usually starts with females laying eggs on ripening cowpea pods in the field (Caswell, 1984). During eclosion, the larvae burrow through the chorion of the egg directly into the pod wall, and then into the seed, where the larvae develop and pupate (Dramani, 2010). Store infestation is frequently derived from harvested products from field-infested pods or seeds but may also come from hidden infestation in the store, respective of source of initial infestation, the infected population consists of relatively few insects that can breed and proliferate to pest proportions in a relatively short time (Dramani, 2010).

The use of chemical strategies or approaches on the control of seed borne fungi on cowpea is hazardous to the environment and dangerous to human consumption. These chemicals are not biodegradable in the environment rather causing soil and air pollution and thus, not readily available. Hence the use of nonchemical approaches, which are safe, environmentally friendly and bio-degradable, was used to control the growth of seed borne fungi on cowpea seed.

This study is aimed at evaluating naturally occurring plant essential oils (biopesticides), as an alternative to fungicides application for the control of seed borne fungi on cowpea (Vigna unguiculata). Recently, Dr. Azawei Alamene 2019, invented a new Bio-pesticide name Alamicide Bio-pesticide that is capable of suppressing the incidence of insect pest and diseasecausing pathogens.

Based on these, the following objectives were evaluated; to determine the percentage $(\%)$ efficacy of plant essential oils., to evaluate the best plant essential oils in the suppression of the pathogen on the cultured Potatoes Dextrose Agar (PDA) plates and to know the best concentration level of the oil against the tested pathogen.

\section{Seed-Borne Fungi infection of Cowpea}

Seed-borne fungi have great limiting factors among other pathogens in the production of cowpea in Botswana. Seed-borne fungi invaded cowpea grains while still in the field or during storage causing seed rotting, mycotoxin contamination and loss of seed viability. The seed infection leads to low germination of seeds, and thus reduced yield loss both quantitatively and qualitatively, been evaluated by series of previous researchers in cowpea grains storage.

Pathogenic fungi have a great ability to infect seeds internally and externally. When the focus of infection is in the inner seed, the damage is more serious, as it may destroy the embryo. Furthermore, seed-borne fungi can contaminate the seeds and cause a great bean cultivar yield losses, affected seed quality, seedling germination and growth. Seed-borne pathogenic fungi also caused diseases on roots, in aerial parts of bean and in other underground body. These fungi can also produce dangerous toxins making the beans inappropriate for both human and livestock consumption (Waller. et al 2002).

Thus, seed-borne fungi are mainly the causal agents of root rot diseases in cowpea and represent the main biotic component of yield decline in an intensively cultivated infected area of land for cowpea production. Seed-borne fungi can survive in soils for longer period and caused root rot influence ranging in severity of disease incidence from declined growth rates to the death of the plant, depending on the host susceptibility and environmental conditions. Fungal pathogens causing root rot can survive in soil and colonize roots of host crops in the mycelium state. In fact, temperature of soil is the main driving force for cowpea development and the physiochemical factor keys of their ecology (Hall 1995). 
Some commonly named examples of seed borne fungi are Pythium spp., Macrophomina phaseolina (Tassi) Goid., Rhizoctonia solani, Kühn., Fusarium oxysporum (Schltdl.) Fr., F. solani (Mart.) Sacc., and Colletotrichum lindemuthianum (Sacc. \& Magnus) which are potential pathogens that are causing serious economic damages in cowpea grains that limit production to a large extent and in a catastrophic manner for farmers for yield losses during storage.

Fungal diseases such as angular leaf spot (Phaeoisariopsis griseola), leaf rust (Uromyces appendiculatus) Pers) Unger, anthracnose (Colletotrichum lindemuthianum, Sacc \& Magn), white mold caused by Sclerotinia sclerotiorum (Lib.), root rot (Fusarium spp and Pythium spp) are diseases with frequent incidence and wide distribution in cowpea growing areas of land that are infected in America. (Schwartz et al. 2005; Hillocks et al. 2006; Singh 2010).

\section{Plant Essential Oils}

Plant essential oils are volatile natural complex secondary metabolites characterized by a strong odour and have a generally lower density than that of water (Bakkali et al., 2008). There are 17,500 aromatic plant species among higher plants and approximately 3,000 plant essential oils are known out of which 300 are commercially important for pharmaceuticals, cosmetics and perfume industries (Bakkaliet al., 2008) apart from the environmental sustainable pesticidal potentials as reported by (Chang and Cheng, 2002). The volatile components of plant essential oils can be classified into four main groups: terpenes, benzene derivatives, hydrocarbons and other miscellaneous compounds (Smit A. et al., 1998).

\section{Plant Essential Oils as Bio-pesticides Against Microbes}

Plant essential oils and other for environmental sustainable bio-pesticides are becoming a new trend for pest management in modern farming and organic agriculture. For two (2) decades, plants essential oils were used as insecticides to control insects for both field and store, however, they have not reached their full potential, because they are rapidly volatile and had low residual activity. They are considered safe, environment-and-eco-friendly, compatible with biological control programme and have low mammals toxicity. Also, plants essential oils are available worldwide for their low to moderate cost. The main active constituents with insecticidal activity are monoterpenes, sesquiterpenes and related phenylpropenes. The plant essential oils can be applied as pesticides as they are or as their active components "Active ingredient" or as co-adjutants in pesticide formulations.

There are some popularly well-known, plant essential oils with bioactivity, either as an insecticide or repellent, such as clove, thyme, mint, lemongrass, cinnamon, rosemary and oregano oils either green or red. Bioactivity can vary greatly because of variability in chemical composition but despite of these variabilities, certain plant species, namely thyme, oregano, basil, rosemary and mint, are consistently bioactive (Isman and Machial, 2006). Elucidation of mode of action of plant essential oils are important or insect control, because it may give useful information on the most appropriate formulation, delivery means and resistance management as reported by (Sim, et al., 2006). Many plant essential oils and their isolates have fumigant action (Kim et al., 2003). Plant Essential oil of Artemisia annua (Tripathi, et al., 2000), Anethum sowa (Tripathi et al. 2001), Curcum alonga (Tripathi, et al., 2002), Lippia alba (Verma, et al. 2001) and isolates like d-limonene (Tripathi, et al., 2003), carvones (Tripathi, et al., 2003) and 1,8-cineole (Aggrawal, et al., 2001) have been well documented as fumigants. 
These findings indicated that the mode of action for the plant essential oils was largely in the vapour phase via respiratory system, although the exact mode of action of these plant essential oils remains unknown from the different research findings

Plant essential oils have been shown to possess antifungal activity and to suppress or inhibit plant pathogenic microorganisms, in both In Vitro and In Vivo experiments (Passone, et al., 2012; and Burt, 2004). Gullino, et al. (2000) also reported that plants produced several bioactive components which have antimicrobial properties. As a result of this findings, feasibility of utilizing plant oils to suppress disease and enhanced food security was seriously evaluated. Antimicrobial components of plant materials comprised phenolics, polyphenols, quinones, flavones, flavonoids and flavonols, tannins, coumarins, terpenoids, alkaloids, lectins and polypeptides were evaluated. Such compounds have been detected from plants which were screened for different antimicrobial activities. Secondary metabolites have been discovered and many more are yet to be explored in the ecosystem particularly in the Niger Delta Area of Nigeria. There are evidence that most of these ingredients were involved in the interaction of plants with other species, basically for defence of plants against pests and plant pathogenic microbes (Tripathi, et al., 2004; Philogene, et al., 2005; Isman and Akhtar, 2007). Plant essential oils are commonly volatile oils, which are liquids at room temperature and derived from many plant tissues, including flowers, buds, seeds, leaves, bark, wood, fruits, and roots. Oils can be obtained through fermentation or extraction processes particularly on steam distillation. However, steam distillation is most often used for commercial production of plant essential oils. About 3000 plant essential oils are known worldwide of these 300 are commercially important in the fragrance market (Van de Braak and Leijten, 1999). The following are some of the plant essential oils that were commonly obtained from plant materials such as ; aniseed, calamus, camphor, cedar wood, cinnamon, citronella, clove, eucalyptus, lavender, lemon, lemongrass, lime, mint, nutmeg, orange, palmarosa, rosemary, basil, vetiver, onion, tea tree, vanilla, neem, garlic, ginger, green oregano, galangal, and wintergreen. These have been traditionally used for different purposes in many parts of the globe. Fifty-one (51) secondary metabolites represented a large reservoir of phyto chemical molecules with bioactivity (Duke et al., 2003). Using such secondary metabolites as bio pesticides remains largely untapped in the Global World and Nigeria. Viewing from the potential advantages of organic pesticides over synthetic compounds, attempts have been made by researchers to screen plants for antimicrobial activity in institutions of higher learning, and to isolate and characterize the bioactive ingredients from the different plant parts. Alpinia galangal essential extract has been evaluated to have inhibitory antioxidant and antimicrobial activities against bacteria which proved effective in suppressing the tested pathogen (Mayachiew and Devahastin, 2008).

\section{MATERIALS AND METHODS}

\section{Location of Experiment}

Experiment on the evaluation on the effect of sustainable environmental friendly bio pesticides on the growth of seed borne fungi on cowpea was conducted at the Department of Crop and Soil Sciences Laboratory, Niger Delta University, Wilberforce Island, Bayelsa State. To determine the efficacy of the plant essential oils as bio-pesticides in suppressing the tested pathogen 


\section{Source of Experimental Materials}

Experimental materials particularly, plant essential oils ( ginger, basil and neem oils) were provided by Dr. A. Alamene, from the University of Nottingham UK while other materials (Petri dish, cowpea seeds, autoclave (from the Laboratory), potato dextrose agar (PDA), mortar and pestle, distilled water (SDW), antibiotics (penicillin and streptomycin), syringe, ethanol, cotton, wool, hand gloves, Cork borer, essentials oils and a digital venire caliper, fitter paper, nose marks, sodium hypochloride) used for the experiment were procured by the researcher, from Doubra Scientific Store at AzikoroYenagoa, Bayelsa State.

\section{Preparations of Samples}

Sample preparation was done after sterilizing the samples with $20 \%$ of sodium hypochloride solution, that is

First $200 \mathrm{~g}$ of cowpea was weighed soaked with $250 \mathrm{ml}$ of serial distilled water for 4 days, the aim of soaking the cowpea was to aid fermentation for pathogen extraction. The fermented seeds were mortared to paste and mixed with $60 \mathrm{ml}$ of serial distilled water filter with a funnel and a filter paper into a screw cap bottle to collect the filtrate from the sample for culturing the tested pathogen.

Nine gram (9g) of Potato Dextrose Agar (PDA) was mixed with $160 \mathrm{ml}$ of distilled water which was autoclaved for 15 mins at $121{ }^{\circ} \mathrm{C}$

\section{Preparation of Serial Dilution}

Serial dilution was carried out to prepared a stock solution form the different plants essential oils with ethanol.

\section{Procedure for the Preparation of Stock Solution (Ten-Fold Serial Dilution)}

$1 \mathrm{ml}$ of each plant essential oil and $9 \mathrm{ml}$ of ethanol was dispersed into universal tube to produce the first stock solution which was vigorously shaken manually for proper mixture of the production to form the stock solution.

$1 \mathrm{ml}$ was pipette from the stock solution into a universal tube and $9.9 \mathrm{ml}$ of serial distilled water was added into the tube to form the first concentration level.

For the second concentration $0.01 \mathrm{ml}$ was pipette from the first concentration and diluted with $9.99 \mathrm{ml}$ of serial distilled water (SDW)

For the third concentration, $0.001 \mathrm{ml}$ was pipette from the second concentration and diluted with $9.999 \mathrm{ml}$ of serial distilled water.

\section{Preparations of Antibiotics for cultured PDA plates}

Five grams $(5 \mathrm{~g})$ each for both penicillin and streptomycin was diluted into $50 \mathrm{ml}$ of sterile distilled water (SDW) respectively for the preparation of antibiotics solution. 


\section{Treatment of Application}

Aspergillus niger cultured Potato Dextrose Agar (PDA) the pathogen was dissected in to small Lomb of colony and placed at the middle of the prepared potato dextrose agar (PDA) plates, four (4) wells were created with cork borer, which represent the three (3) levels of concentration of the plant essential oils and the control (little drop of ethanol was dispensed into the first well that serve the control) while the other three wells were used for the treatments. The different concentration levels of the plant essential oils was pipette and dispensed into the wells that were created with the cork borer. This process of treatment application is called agar well point inoculation method was used to ascertain the efficacy of the EOs

\section{Experimental Designs}

Complete randomized design was used for the experiment and treatments were replicated three times. In each of the replicate.

Below is the layout of the experiment.

\section{REP1}
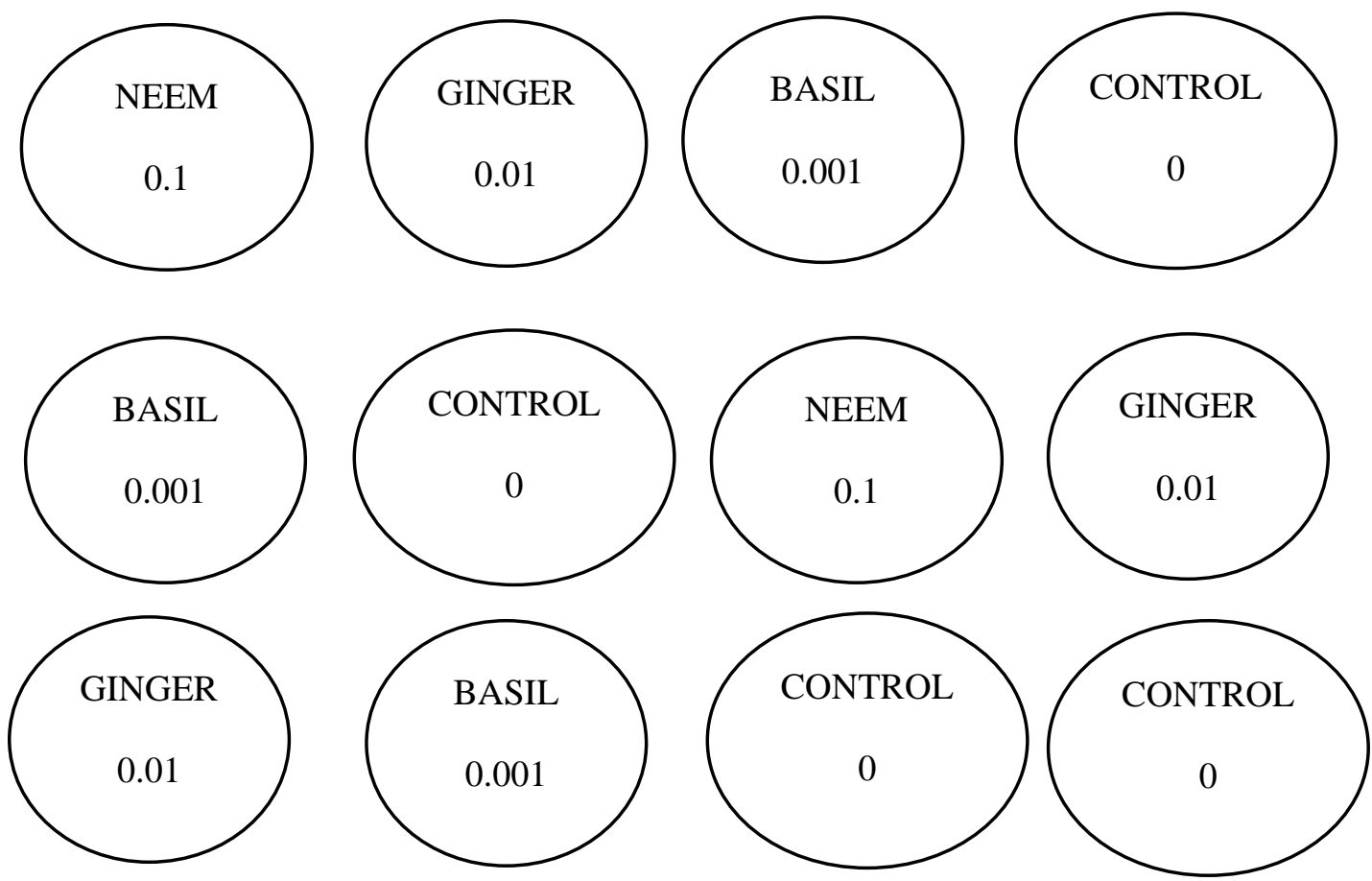
REP 2
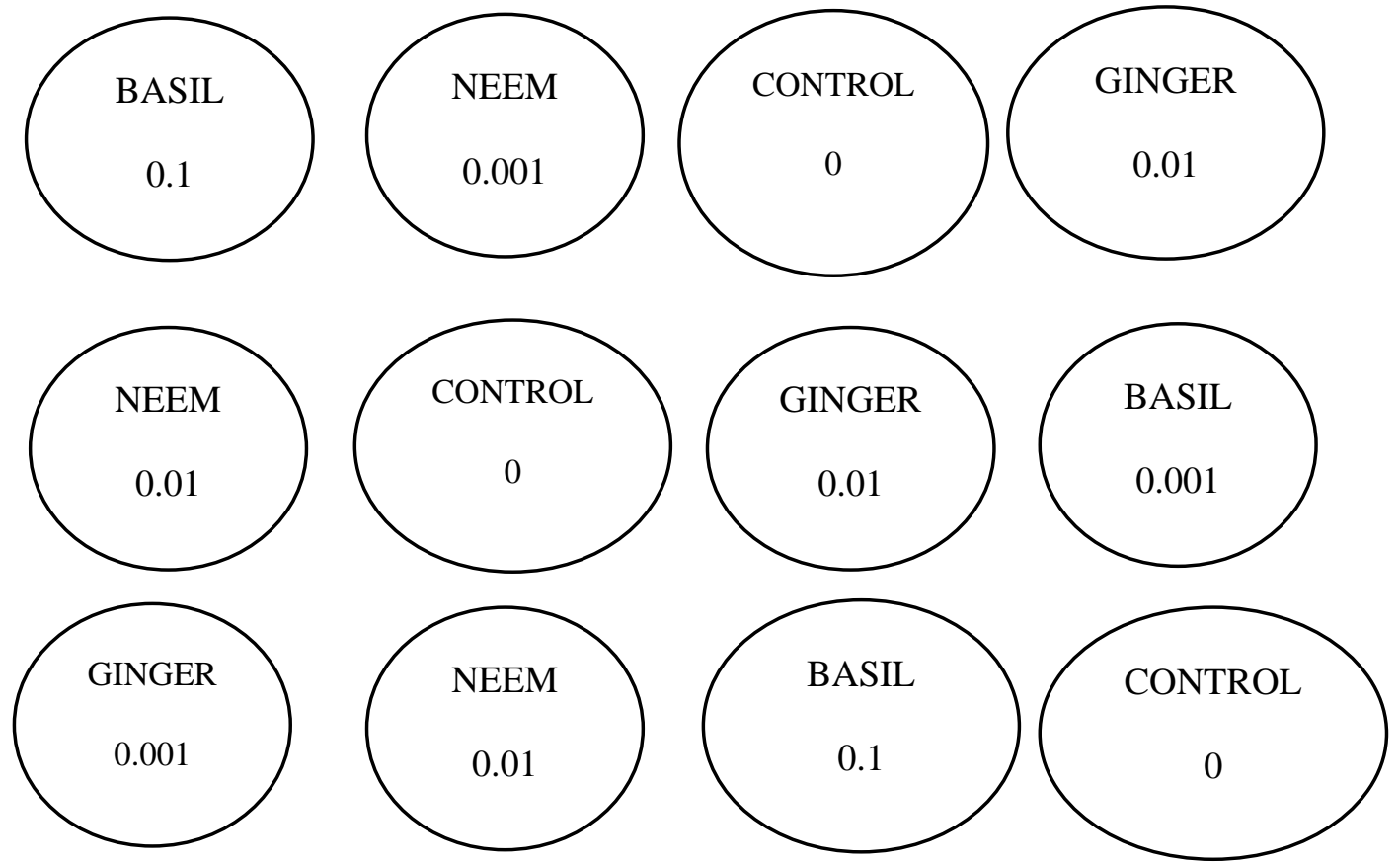

REP 3
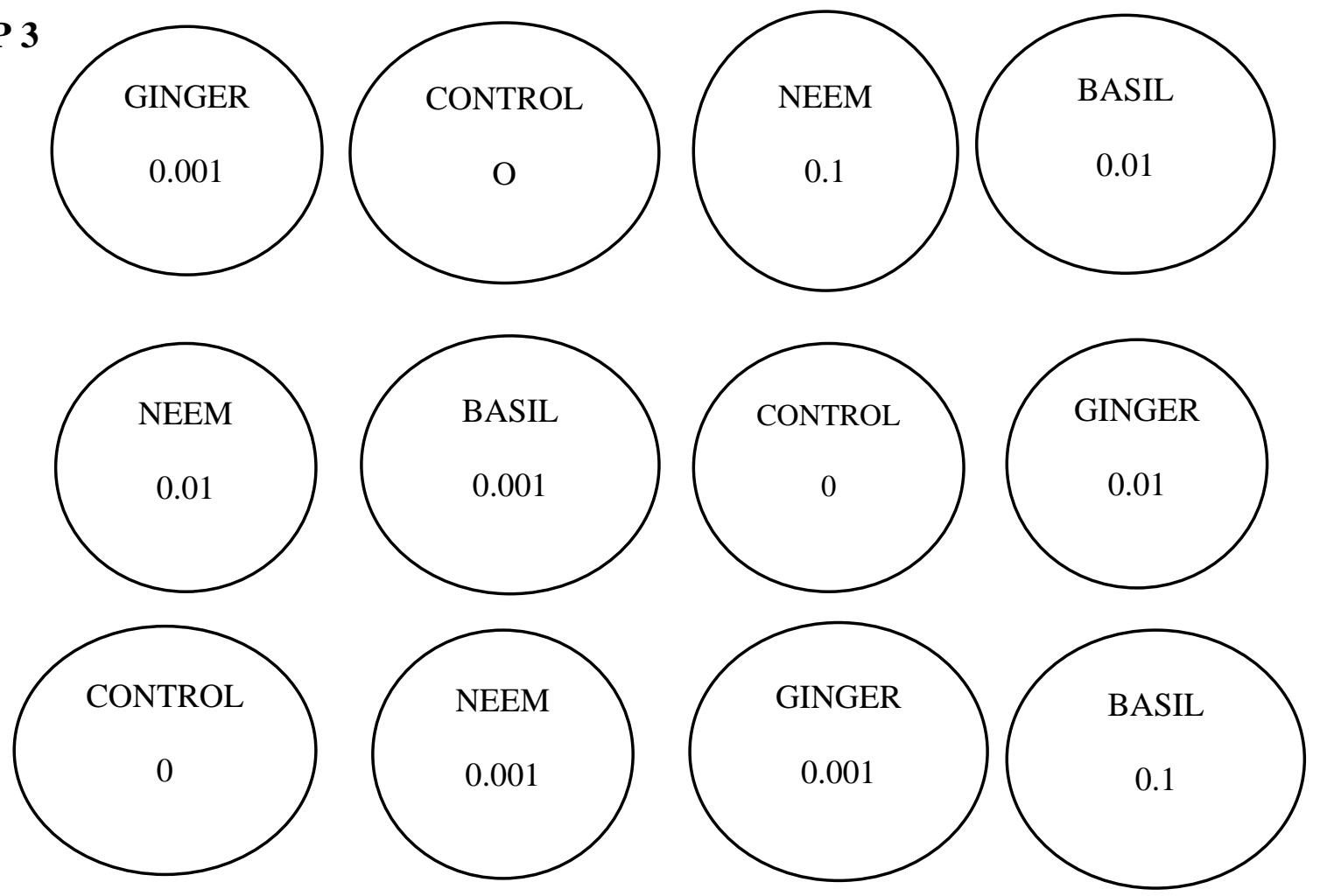

\section{Parameters Accessed}

Parameters were evaluated in accordance with the following objectives

- To ascertain the inhibition level of the plant essential oil against seed-borne fungi.

- To identify the efficacy of the best plant essential oil of pathogen inhibition.

- To know the best concentration level of plant essential oils against the tested pathogen. 


\section{Experimental Data Collection}

Data were collected daily after 4 days of the treatment in cultured PDA plates Fourteen days was used for data collection and manual venier caliper was used to measure the radial colony of the pathogen on the different replicate, 12 petri dishes per replicate which was replicated three times.

\section{Data Analysis}

Data were collected and subjected to two-way analysis of variance, and significant treatment between means within and across rows were separated using Fisher Least significance difference (LSD) at 5\% level of probability using sigma plot v12 statistical software.

\section{RESULTS AND DISCUSSION}

The result of this experiment on The Effect of Bio pesticide on the Growth of Seed Borne Fungi on Cowpea shown below.

Result shown in Fig. 1-10. indicated that ginger oil at $0.1 \%$ suppressed the growth colony of fungi isolated from cowpea, this oil was more effective when compared to Neem and basil oils, alongside with control.

Ginger oil was found to be more effective followed by neem oil, while basil oil has no significant difference when compared to the control.

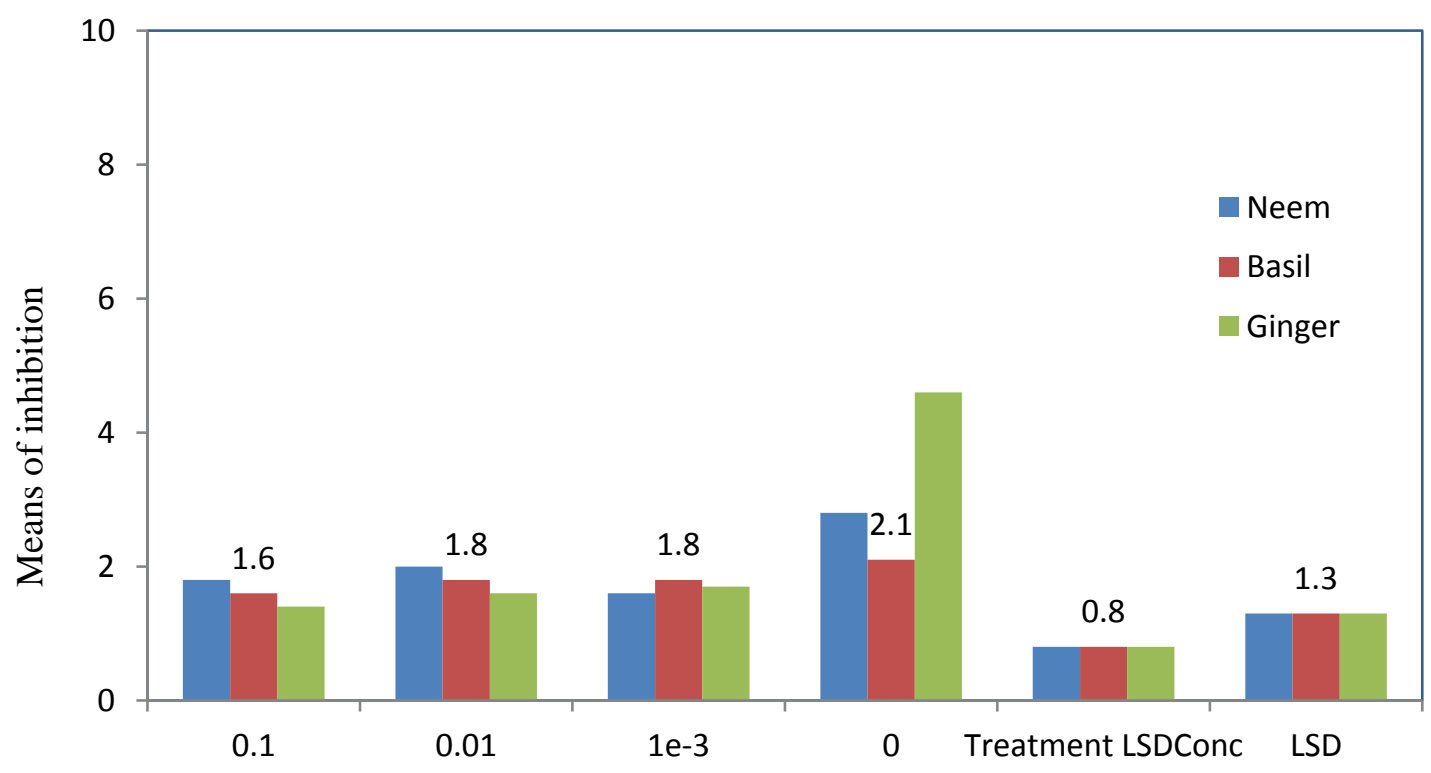

Treatment Levels

Fig. 1. Efficacy of antifungal activities of plant essential oils (EOS) evaluated at the different concentration levels against the pathogen tested on Agar Well Point

Inoculation Method 5 days after treatment application, to determine the radial zones of colony inhibition 


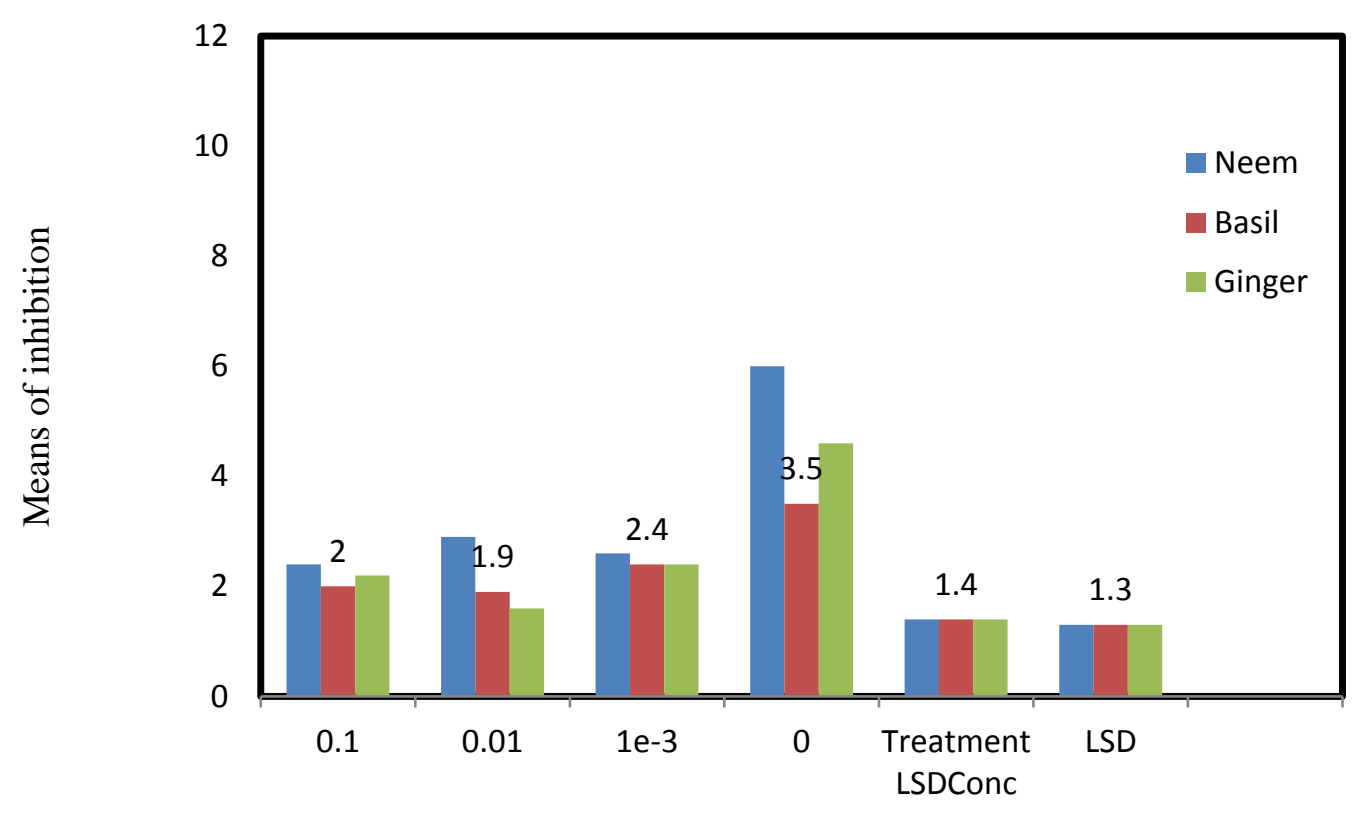

Treatment levels

Fig. 2. Efficacy of antifungal activities of plant essential oils (EOS) evaluated at the different concentration levels against the pathogen tested on Agar Well Point Inoculation Method 6 days after treatment application, to determine the radial zones of colony inhibition

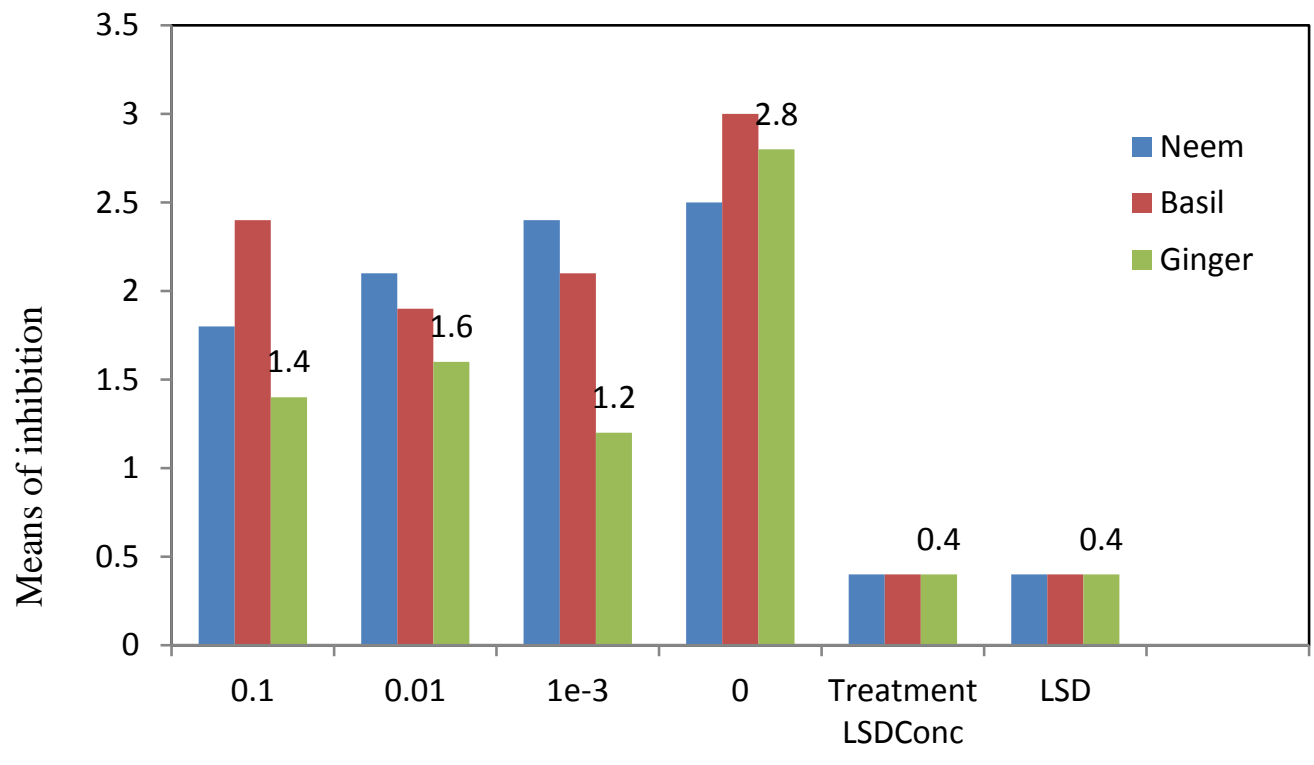

Treatment levels

Fig. 1. Efficacy of antifungal activities of plant essential oils (EOS) evaluated at the different concentration levels against the pathogen tested on Agar Well Point Inoculation Method 7 days after treatment application, to determine the radial zones of colony inhibition 


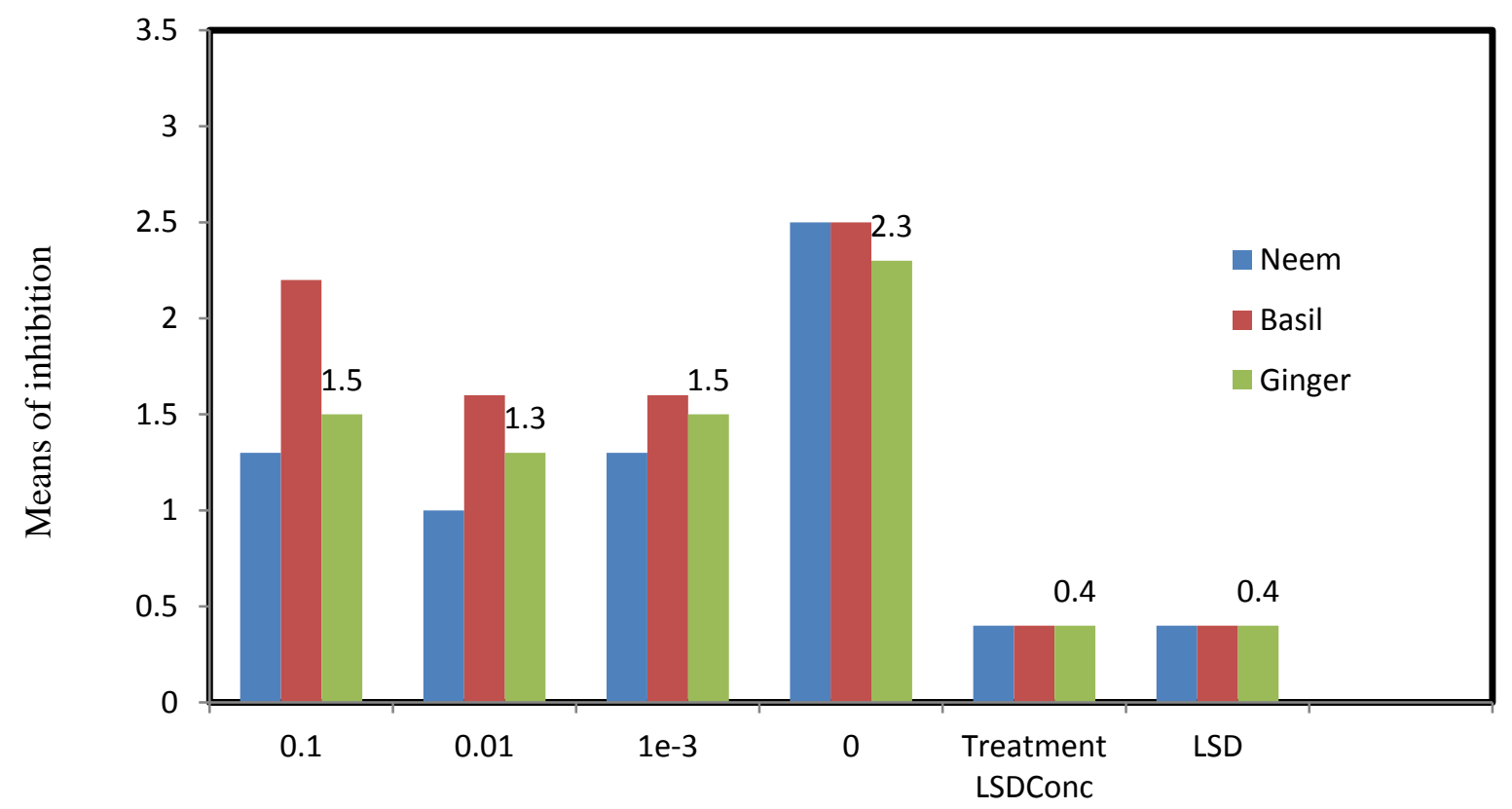

Treatment levels

Fig. 4. Efficacy of antifungal activities of plant essential oils (EOS) evaluated at the different concentration levels against the pathogen tested on Agar Well Point Inoculation Method 8 days after treatment application, to determine the radial zones of colony inhibition

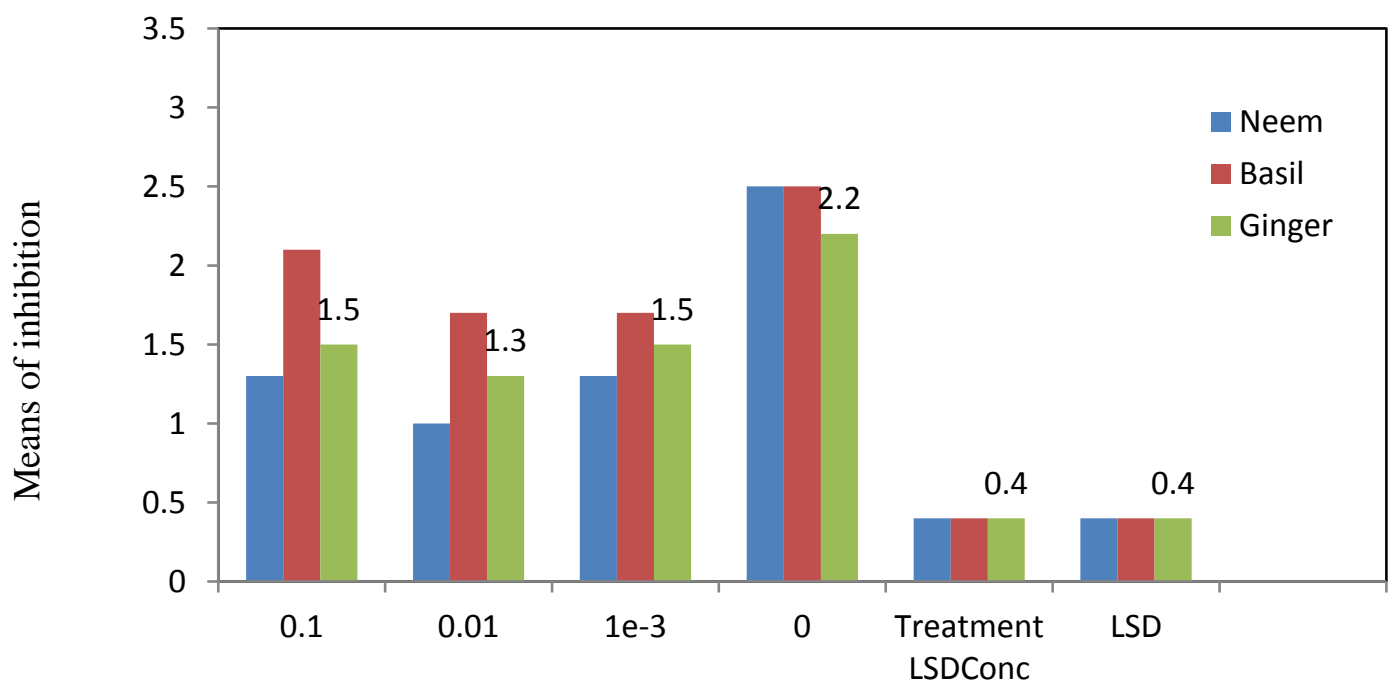

Treatment levels

Fig.5. Efficacy of antifungal activities of plant essential oils (EOS) evaluated at the different concentration levels against the pathogen tested on Agar Well Point Inoculation Method 9 days after treatment application, to determine the radial zones of colony inhibition 


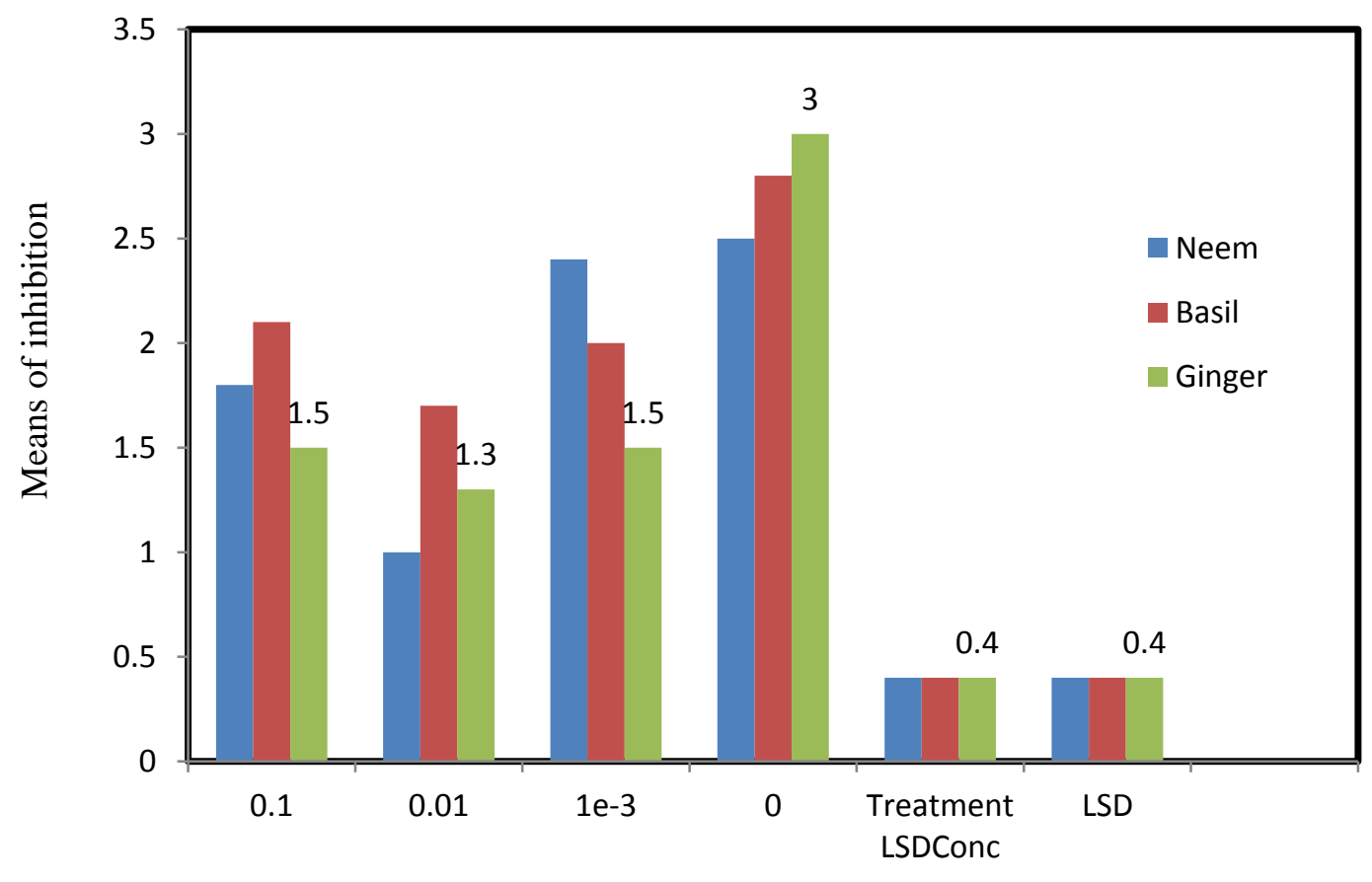

Treatment levels

Fig. 6. Efficacy of antifungal activities of plant essential oils (EOS) evaluated at the different concentration levels against the pathogen tested on Agar Well Point Inoculation Method 10 days after treatment application, to determine the radial zones of colony inhibition

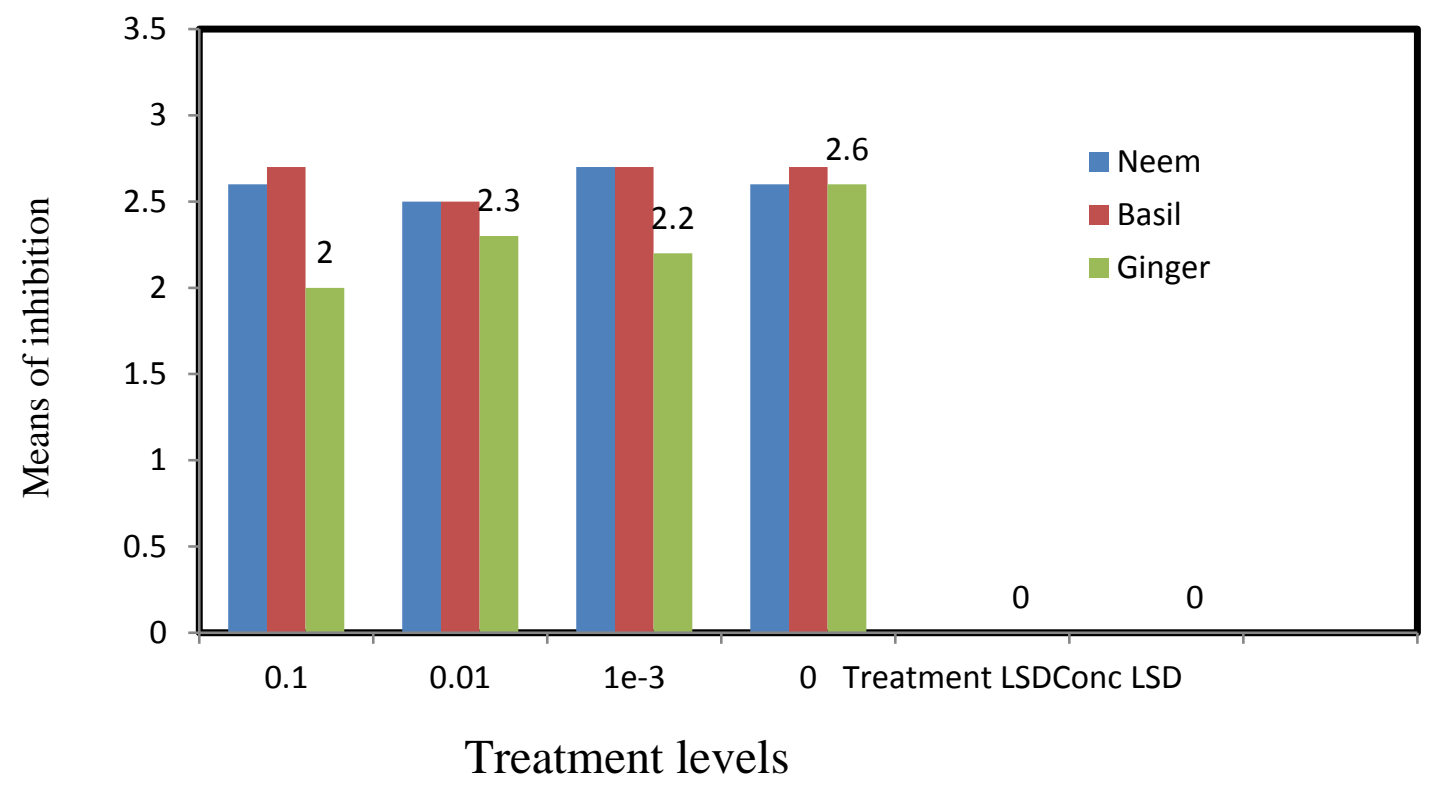

Fig. 7. Efficacy of antifungal activities of plant essential oils (EOS) evaluated at the different concentration levels against the pathogen tested on Agar Well Point Inoculation Method 11 days after treatment application, to determine the radial zones of colony inhibition 


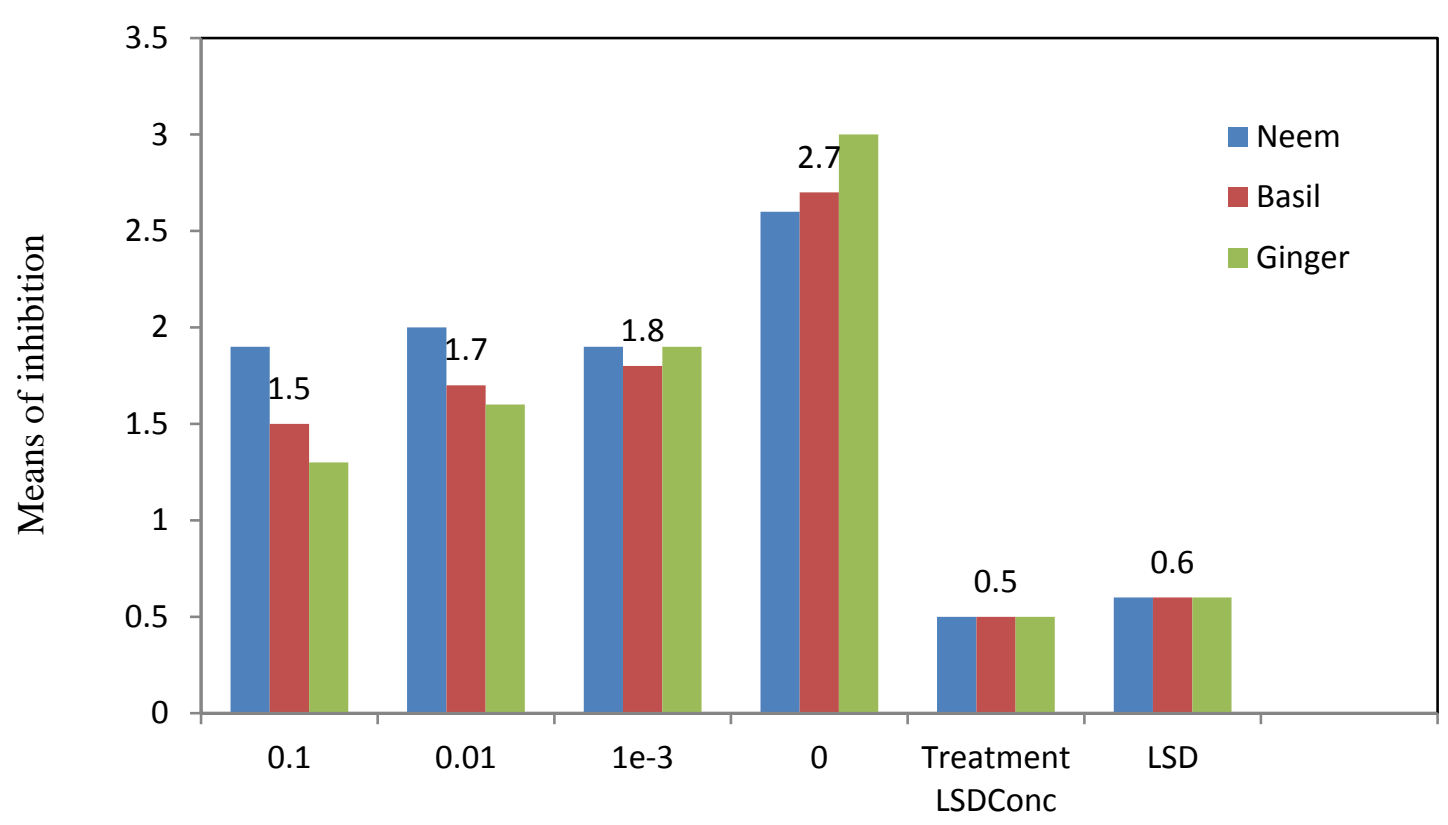

Treatment levels

Fig. 8. Efficacy of antifungal activities of plant essential oils (EOS) evaluated at the different concentration levels against the pathogen tested on Agar Well Point Inoculation Method 12 days after treatment application, to determine the radial zones of colony inhibition

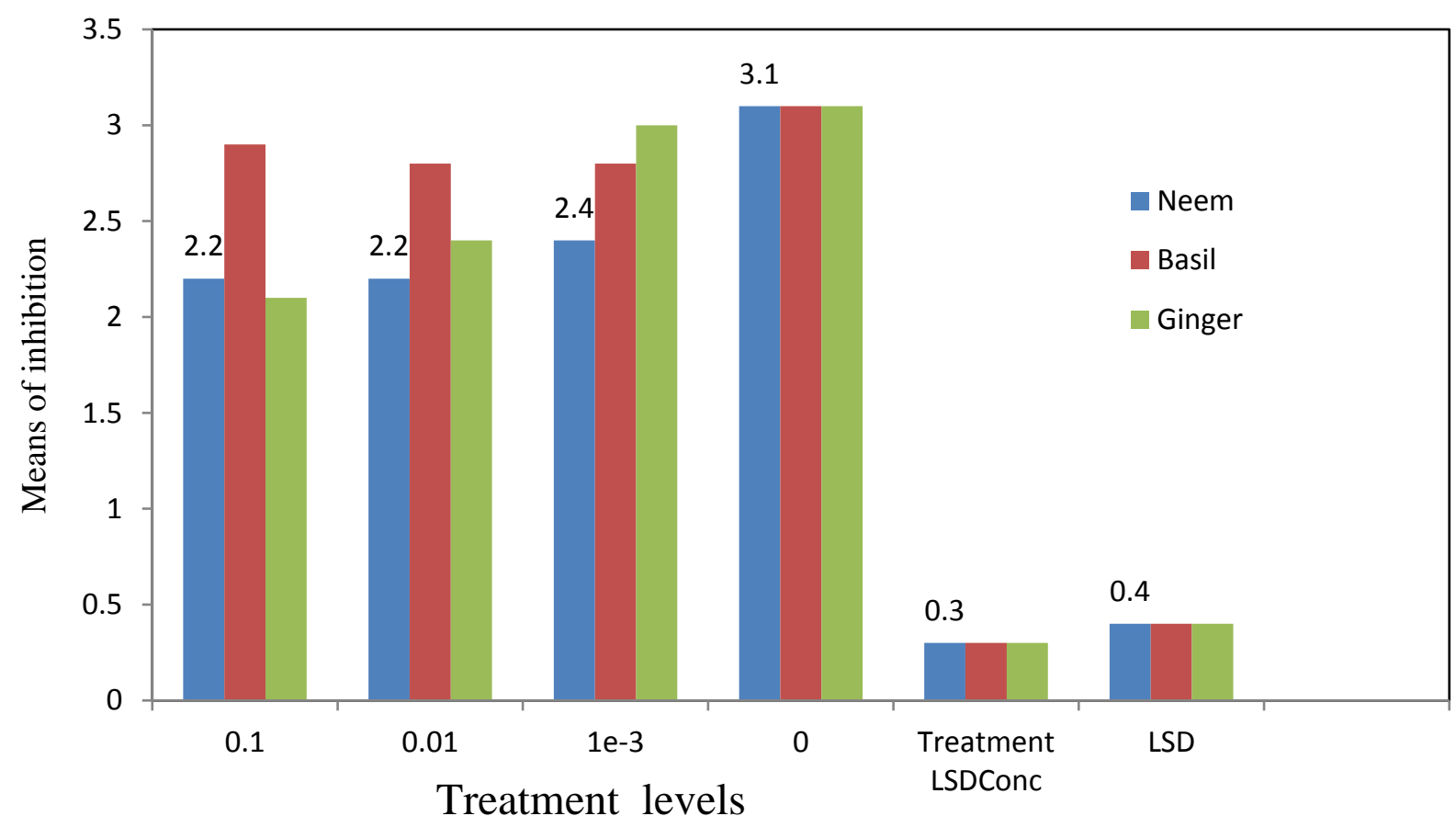

Fig. 9. Efficacy of antifungal activities of plant essential oils (EOS) evaluated at the different concentration levels against the pathogen tested on Agar Well Point Inoculation Method 13 days after treatment application, to determine the radial zones of colony inhibition 


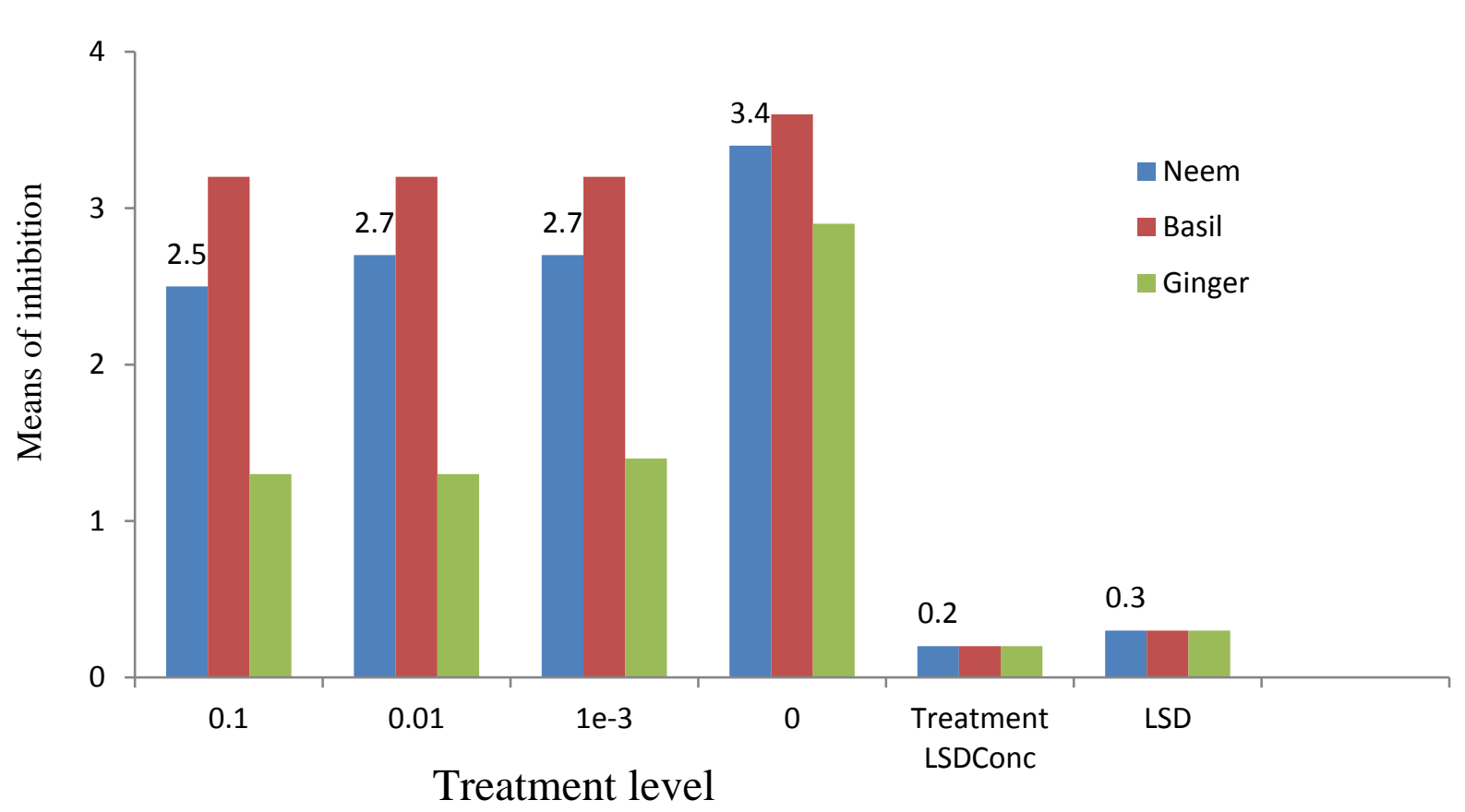

\section{Fig. 10. Efficacy of antifungical activities of plant essential oils (EOS) evaluated at the different concentration levels against the pathogen tested on Agar Well Point Inoculation Method 14 days after treatment application, to determine the radial zones of colony inhibition}

Generally, the experimental research findings showed that ginger at $0.1 \%$ was effective in pathogen suppression, from day 6 to day 10, its active ingredients were more effective in the reduction of the colony against the tested pathogen.

The plant essential oils used as pesticides are (gingers, neem and basil oils), ginger oil is more preferable, this current research findings are in line with the finding of Rubasinghefi et al. 2004 who reported that characteristic of odour in the oil treated grains was due to the absorption of oil with its peppery taste of the pesticides might enhanced the efficacy also, according to (Isman and Machail, 2006) reviewed that essential oils with bioactivity, were used as insecticides that had repellant property in pathogen inhibition or suppression. Plant essential oils have shown to possess antifungal activity and to suppress or inhibit plant pathogenic microorganism, in both in Vitro and in Vivo experiments as reported by (Passons et al. 2012; and Burt, 2004). Gullino et al. 2000, also reported that plants produced several bioactive components which have antimicrobial properties as a result of its findings, feasibility of utilizing plants oils to suppress disease and enhanced food security was seriously evaluated by different scientists. Antimicrobial components commonly comprised phenolic, polyphenols, quinines, flavones, flavonoids and flavonols, etc. such compound are detected form plant components which were screened for different usages for human wellbeing. Particularly for the control of the pathogenic seed-soil microbes in stored grains and insect repellent and antifeedant as preservatives in stored agricultural food commodities. 


\section{CONCLUSION AND RECOMMENDATION}

\section{Conclusion}

Having satisfied the objectives of this research project work, it is important to note that Biopesticides (plant essentials oils) are environmental friendly as alternative for the replacement of synthetics fungicides, because of their toxic nature. Hence, plant essential oil were used. These plant essential oils were readily available in our local environment, safe and friendly to the ecosystem, and are biodegradable. The use of these bio pesticide (plants material) are highly recommended especially despite the discovery of low oils contents, they can still be used as a preservative against pest and disease incidents to increase rapid cowpea production for safe food insecurity. Based on the results obtained in this current research work, the following recommendations should be encouraged for farmers that are involved in cowpea production.

\section{Recommendation}

This current research project, have proved to the Global World that bio-pesticides of plant based materials have good potentials qualities in suppressing the growth of seed borne fungi of stored grains of crops particularly, Ginger at $0.1 \%$ suppressed the tested pathogen of cowpea, from the $6^{\text {th }}$ day to the $10^{\text {th }}$ day were the efficacy was more preannounced in the reduction of the pathogen colony against $A$. niger Therefore, ginger at 0.1 concentration should be encouraged as preservative protocols as bio pesticide on stored cowpea grains against seedborne pathogen. infection

\section{REFERENCES}

Agboola S. A. (1979). An Agricultural Atlas of Nigeria, Oxford University Press, London. pp 95-97

Agwu A.E (2001). Commercialization of agricultural extension services deliver in Nigeria. Prospects and problems proceeding of the seventh annual national conference of the agricultural extension society of Nigeria.

Ahmedna M. Prinyawiwatkul W., Rao R. M (1999). Solubilized Wheat Protein Isolat: Functional Properties and Properties and Potential Food Application. Journal of Agriculture and Food Chemistry. 50:4674-81

Ajeighe H. A., Abdoulaye T., and Chikoye D. Development of Cowpea Cultivars and Germplasm by the Bean/ Cowpea CRcorrec Citation.

Ali, I. (2008). Storage systems of Cowpea and their implications for pests 'management in the Tamale Metropolis, BSc. Dissertation, UDS, Tamale; pp. 43-49.

Alzouma, I. (1981), Observations on the ecology of Bruchidiusatrolineatus Pic. And Callosobruchusmaculatus (F.) in Niger. In: V. Labeyrie (Editor). The Ecology of Bruchids Attacking Legumes, Junk, The Hague, pp. 205-213.

Bakkali, F. et al. Food ChemToxicol. 2008. Reviewed Works: John Bunyan's “Grace Abounding" and "The Pilgrim's Progrss": An Overview of Literacy Studies, 1986 Bunyan in Our Time by Robert G. Collmer; John Bunyan: Conventicle and Parnassus by N. H. Keeble. Wekidipdia.org>node.

Barrett, R.P. (1990): Legume species as leaf vegetables. p. 391-396. In: J. Janick and J.E. Simon (eds.), Advances in new crops. Portland, OR: Timber Press 
Bawa L. Y., Oparaeke A. M., and Ainika J. N (2012). Cowpea (Vignaunguiculata) Pest Control Methods in Storage and Recommended Practices for Efficiency: A Review. Journal of

Biology, Agriculture and Healthcare www.iiste.org ISSN 2224-3208 (Paper) ISSN 2225093X (Online) Vol 2, No.2

Crouch J. H., Crouch H. K. \& Ortiz, R. (1998). International Institute of Tropical Agriculture, Ibadan, Nigeria $50 \mathrm{pp}$.

Cycle, Economic Importance and Potential Control. In singh, R. S and Rachie, K. O. (eds).Cowpea research production and utilization (CRPU) John Willey, S. R and Sons Ltd pp 217-231.

Dramani, K. (2010). Comparative study of cowpea storage in different storage structures. Project report submitted to the Department of Agricultural engineering.Germany, MSc Thesis

Elawad, Hassan O. A., ehlers, Jeffrey D., Ismail, Abdelbagi M., Fery, Richard L., Roberts, Philip A., Kitch, Laurie W., Murdock, Larry L., boukar, Ousmane, Philip, R. D., Mc Watters, K. H. (2003).

Ezeaku\& Mohamed Final Project Report Garsby Improved Crop-livestock project (Project no. GAT2833) Improved Crop-livestock System for Enhance food Security and Income generation in West Africa) 2005.

GIAHS Programme, (2006). A Candidate System for the Globally - Important Indigenous Agricultural heritage).

Gibbon, D and Pain, A (1985).crops of the drier regions of the tropics. Longman Group. Singapore pp. 111-112

Gungula,D.TandGarjila, Y (2005). The effects of phosphorus application on growth and yield of cowpea in yola. Journal of Sustainable Development in Agriculture Environment $1(1)$

Iwe M. O. \& Onalope O. O. (2001). Effect o Extrude Full-Fat soy flour into Sweet Potato Flour on Functional Properties and Amylopectin Chain Properties of the Mixture. Journal of Sustainable Agriculture and Environment, 3, 109-117.

KELLER, GB. (2004): African Nightshade, eggplant, spiderflower et al. - production and consumption aspects of traditional vegetables in Tanzania from the farmers point of view. Goettingen: Georg-August Universität,

Kethireddipalli, P. Hung, YC; McWatters, K. H. (2002) Baking Performance and Consumer Ability of Raw Extrude Cowpea Flour Bread J. Food Qual. 27:337-351

Koppelman: Antimicrobial and Antioxidant Activities of Indian Goosebery and Galangal Extract. 2003.

Langyintuo, A. S., \&Lowwenberg-DoBoer, J. (2006). Potential Regional Trade Implication of Adopting Bt Cowpea in West and Central Africa. AgBioForum.

Mayachiew P. \& Devahasitn S. -LWT- Food Science and Technology, 2008.

McWatters, K. H., Hung, C. -Y. T., Chinnan, and et al (2001). Akara-making Characteristic of five variety of Cowpeas (Vigna unguiclata) J. Food Qual. 24: 53-65.

Musa Naga. "Genetic Diversity, Hybrid Performance and Combining Ability for Yield in Project (Central Sudan)". Poznana Archaeological Muslem. Retrieved January 17, 2018.

Philips R.D., McWatters K. H., MsChinnan, et al. (2003). Field Crops Research 82 (2-3), 193-213, 2003143 Utilization of Cowpea for Human Food. 
Philips, R. D., Chinnan, M.Sc (2006) Effect of saponins on the physical Characteristics, Composition and Quality of Akara (Fried Cowpea Paste)Made from non-decorticated Cream Cowpea Effect of Saponis on the Physical Characteristics, Composition and Quality of Akara (Fried Cowpea Paste) Labensmittel-Wissenschaft (i.e. und) Technologies, 2006.

Philips, R.D. 2002. Effect of Milling Method (Wet and Dry) on the Functional Propertis of Cowpea (Vignaunguiculate) Pastes and End Product (Akara) Journal of Food Science. v.67.

Reverberi, M; Ricelli, A; Zjalic, S; Fabbri, AA; Fanelli, C (2010). Natural functions of mycotoxins and control of their biosynthesis in fungi. Appl. Microbiol. Biotechnol.87:899-911.

Sajo, A.A and Kadams, A.M (1999). Food and cash crops in A.A. Adebayo and A.I. .Tukur (eds). Adamawa State in Maps, Yola, Nigeria. Paraclete Publishers pp 37-40.

Sathivel S., Liu Q., Huang J., Prinyawiwatkul W. (2007). The Influence of Chitosan Glazing on the Quality of Skinless Pink Salmon (Oncorhynchusgorbuscha) Fillets During Frozen Storage Journal of Good Engineering 83(3), 366-373, 140.

Sathivel, P.J. Bechtel, J. Babbit, S. Smiley, C. Crapo, K.D. Reppond, Journal of Food Science 68(7),2196-2200, 2003.

Sharma, RR; Singh, D; Singh, R (2009). Biological control of postharvest diseases of fruits and vegetables by microbial antagonists: A review. Bio. Control 50(3): 205-221.

Singh, B.B., Ajeigbe, H.A., Tarawali, S.A., Fernandez-Rivera, S. and Musa Abubakar (2003). Improving the production and utilization of cowpea as food and fodder. Field Crops Research 84(1-2):169-177.

Tripathi, M. K.: Agrawal, I. S.; Sharma, S. D.: Mishra, D. P., 2001. Effect of Substitution of Soybean Meal with Treated or Untreated High Can be Trace Back to Industrial Engineering Son the Factory Floor in the Late 1800s.

UNEBobLowenbrg M. D., Gert J. Ossenkoppele M. D., Wim Van Putten, M.Sc, et al. 2000. Dutch-Belgian cooperative Trail (AMLSG), and Swill Group for Clinical Cancer Research (SAKK) Collaborative Group. 


\section{APPENDIX}

\section{TWO-WAY ANOVA TABLE}

ANOVA A DAY ONE OIL INHIBITION

Analysis of Variance

$\begin{array}{lllllll}\text { Source } & \text { DF } & \text { Adj SS } & \text { Adj MS } & \text { F-Value } & \text { P-Value } & \text { LSD(alph=0.05 } \\ \text { Treatment } & 2 & 3.472 & 1.736 & 1.70 & 0.204 & 0.857 \\ \text { Concentration } & 3 & 16.732 & 5.577 & 5.47 & 0.005 & 0.98 \\ \text { Treatment* } & 6 & 6.919 & 1.153 & 1.13 & 0.375 & \\ \text { Concentration } & & & & & & \\ \text { Error } & 24 & 24.481 & 1.020 & & & \\ \text { Total } & 35 & 51.604 & & & & \end{array}$

ANOVA DAY TWO OIL INHIBITION

Analysis of Variance

$\begin{array}{lllllll}\text { Source } & \text { DF } & \text { Adj SS } & \text { Adj MS } & \text { F-Value } & \text { P-Value } & \text { LSD(alph=0.05 } \\ \text { Treatment } & 2 & 9.320 & 4.660 & 3.47 & 0.047 & 0.976 \\ \text { Concentration } & 3 & 16.558 & 5.519 & 4.11 & 0.017 & 1.127 \\ \text { Treatment* } & 6 & 6.332 & 1.055 & 0.79 & 0.589 & \\ \text { Concentration } & & & & & & \\ \text { Error } & 24 & 32.217 & 1.342 & & & \\ \text { Total } & 35 & 64.427 & & & & \end{array}$

\section{ANOVA DAY THREE ON INHIBITION}

Analysis of Variance

$\begin{array}{lllllll}\text { Source } & \text { DF } & \text { Adj SS } & \text { Adj MS } & \text { F-Value } & \text { P-Value } & \text { LSD(alph=0.05 } \\ \text { Treatment } & 2 & 1.827 & 0.9136 & 6.14 & 0.007 & 0.325 \\ \text { Concentration } & 3 & 4.439 & 1.4796 & 9.95 & 0.000 & 0.375 \\ \text { Treatment* } & 6 & 1.673 & 0.2788 & 1.87 & 0.127 & \\ \text { Concentration } & & & & & & \\ \text { Error } & 24 & 3.569 & 0.1487 & & & \\ \text { Total } & 35 & 11.508 & & & & \end{array}$


ANOVA DAY FOUR OIL INHIBITION

Analysis of Variance

$\begin{array}{lllllll}\text { Source } & \text { DF } & \text { Adj SS } & \text { Adj MS } & \text { F-Value } & \text { P-Value } & \text { LSD(alph=0.05 } \\ \text { Treatment } & 2 & 2.1409 & 1.0725 & 5.79 & 0.009 & 0.362 \\ \text { Concentration } & 3 & 5.6595 & 1.8865 & 10.20 & 0.000 & 0.418 \\ \text { Treatment* } & 6 & 0.7438 & 0.1240 & 0.67 & 0.674 & \\ \text { Concentration } & & & & & & \\ \text { Error } & 24 & 4.4379 & 0.1849 & & & \\ \text { Total } & 35 & 12.9821 & & & & \end{array}$

\section{ANOVA DAY FIVE OIL INHABITATION}

Analysis of Variance

$\begin{array}{lllllll}\text { Source } & \text { DF } & \text { Adj SS } & \text { Adj MS } & \text { F-Value } & \text { P-Value } & \text { LSD(alph=0.05 } \\ \text { Treatment } & 2 & 3.7694 & 1.88470 & 9.11 & 0.001 & 0.383 \\ \text { Concentration } & 3 & 5.7241 & 1.90803 & 9.22 & 0.000 & 0.443 \\ \text { Treatment* } & 6 & 0.3541 & 0.05901 & 0.29 & 0.938 & \\ \text { Concentration } & & & & & & \\ \text { Error } & 24 & 4.9661 & 0.20692 & & & \\ \text { Total } & 35 & 14.8137 & & & & \end{array}$

\section{ANOVA DAY SIX OIL INHIBITION}

Analysis of Variance

$\begin{array}{lllllll}\text { Source } & \text { DF } & \text { Adj SS } & \text { Adj MS } & \text { F-Value } & \text { P-Value } & \text { LSD(alph=0.05 } \\ \text { Treatment } & 2 & 0.5012 & 0.2510 & 1.88 & 0.175 & 0.38 \\ \text { Concentration } & 3 & 6.2166 & 2.0722 & 15.50 & 0.000 & 0.356 \\ \text { Treatment* } & 6 & 1.1908 & 0.1985 & 1.48 & 0.226 & \\ \text { Concentration } & & & & & & \\ \text { Error } & 24 & 3.2093 & 0.1337 & & & \\ \text { Total } & 35 & 11.1188 & & & & \end{array}$


ANOVA DAY SEVEN OIL INHABITATION

Analysis of Variance

$\begin{array}{lllllll}\text { Source } & \text { DF } & \text { Adj SS } & \text { Adj MS } & \text { F-Value } & \text { P-Value } & \text { LSD(alph=0.05 } \\ \text { Treatment } & 2 & 0.5069 & 0.25343 & 3.28 & 0.055 & 0.000 \\ \text { Concentration } & 3 & 0.5377 & 0.17923 & 2.32 & 0.101 & 0.000 \\ \text { Treatment* } & 6 & 0.3754 & 0.06257 & 0.81 & 0.573 & \\ \text { Concentration } & & & & & & \\ \text { Error } & 24 & 1.8543 & 0.07726 & & & \\ \text { Total } & 35 & 9.2743 & & & & \end{array}$

\section{ANOVA DAY EIGHT OIL INHABITATION}

Analysis of Variance

$\begin{array}{lllllll}\text { Source } & \text { DF } & \text { Adj SS } & \text { Adj MS } & \text { F-Value } & \text { P-Value } & \text { LSD(alph=0.05 } \\ \text { Treatment } & 2 & 0.3205 & 0.1602 & 0.79 & 0.464 & 0.379 \\ \text { Concentration } & 3 & 7.4720 & 2.4907 & 12.34 & 0.000 & 0.437 \\ \text { Treatment* } & 6 & 0.7206 & 0.1201 & 0.60 & 0.731 & \\ \text { Concentration } & & & & & & \\ \text { Error } & 24 & 4.8440 & 0.2018 & & & \\ \text { Total } & 35 & 13.3571 & & & & \end{array}$

\section{ANOVA DAY NINE OIL INHIBITATION}

Analysis of Variance

$\begin{array}{lllllll}\text { Source } & \text { DF } & \text { Adj SS } & \text { Adj MS } & \text { F-Value } & \text { P-Value } & \text { LSD(alph=0.05 } \\ \text { Treatment } & 2 & 0.9455 & 0.47274 & 7.61 & 0.003 & 0.210 \\ \text { Concentration } & 3 & 2.6852 & 0.89507 & 14.40 & 0.000 & 0243 \\ \text { Treatment* } & 6 & 1.0981 & 0.18301 & 2.94 & 0.027 & \\ \text { Concentration } & & & & & & \\ \text { Error } & 24 & 1.4918 & 0.06216 & & & \\ \text { Total } & 35 & 6.2206 & & & & \end{array}$




\section{ANOVA DAY TEN OIL INHABITATION}

Analysis of Variance

$\begin{array}{lllllll}\text { Source } & \text { DF } & \text { Adj SS } & \text { Adj MS } & \text { F-Value } & \text { P-Value } & \text { LSD(alph=0.05 } \\ \text { Treatment } & 2 & 13.975 & 6.98770 & 105.66 & 0.000 & 0.217 \\ \text { Concentration } & 3 & 2.961 & 0.98699 & 14.92 & 0.000 & 0.250 \\ \text { Treatment* } & 6 & 1.360 & 0.22671 & 3.43 & 0.014 & \\ \text { Concentration } & & & & & & \\ \text { Error } & 24 & 0.22671 & 0.6613 & & & \\ \text { Total } & 35 & 0.06613 & & & & \end{array}$

TABLE 1

Effect of Plant Essential Oils at Different Levels on Fungi Inhibition (DAY ONE)

\begin{tabular}{llrrc}
\hline TREATMENT & $\mathbf{0}$ & $\mathbf{0 . 0 1}$ & $\mathbf{0 . 0 1}$ & $\mathbf{0 . 0 0 1}$ \\
\hline Neem & $2.74 \pm 0.16 \mathrm{ab}$ & $1.44 \pm 0.19 b$ & $1.34 \pm 0.23 \mathrm{~b}$ & $1.46 \pm 0.25 b$ \\
Basil & $2.07 \pm 11.50 \mathrm{ab}$ & $1.47 \pm 2.97 \mathrm{~b}$ & $1.59 \pm 6.15 \mathrm{ab}$ & $1.65 \pm 33.40 \mathrm{ab}$ \\
Ginger & $4.54 \pm 29.30 \mathrm{a}$ & $1.71 \pm 23.00 \mathrm{ab}$ & $.1 .84 \pm 47 \mathrm{ab}$ & $1.41 \pm 33.10 \mathrm{~b}$
\end{tabular}

\section{TABLE 2}

Effect of Plant Essential Oils at Different Levels on Fungi Inhibition (DAY TWO)

\begin{tabular}{lcccc}
\hline TREATMENT & \multicolumn{1}{l}{} & $\mathbf{0 . 0 1}$ & $\mathbf{0 . 0 1}$ & $\mathbf{0 . 0 0 1}$ \\
\hline Neem & $5.39 \pm 8.36 a$ & $2.35 \pm 6.27$ & $2.90 \pm 7.43$ & $2.68 \pm 11.03 a$ \\
Basil & $2.70 \pm 20.1 a b$ & $1.95 \pm 7.12 a b$ & $1.99 \pm 10.33 a b$ & $2.27 \pm 16.32 a b$ \\
Ginger & $3.23 \pm 0.21 a b$ & $2.11 \pm 0.34 a b$ & $2.11 \pm 0.31 b$ & $2.19 \pm 0.17 a b$ \\
\hline
\end{tabular}

\section{TABLE 3}

Effect of Plant Essential Oils at Different Levels on Fungi Inhibition (DAY THREE)

\begin{tabular}{llllc}
\hline TREATMENT & $\mathbf{0}$ & $\mathbf{0 . 0 1}$ & $\mathbf{0 . 0 1}$ & $\mathbf{0 . 0 0 1}$ \\
\hline Neem & $2.42 \pm 0.26 a b$ & $1.80 \pm 11.67 a b c d$ & $1.98 \pm 0.12 a b c d$ & $2.23 \pm 4.85 a b c d$ \\
Basil & $2.76 \pm 0.16 a$ & $2.16 \pm 4.42 a b c d$ & $1.77 \pm 0.18 a b c d$ & $2.10 \pm 18.86 a b c d$ \\
Ginger & $2.63 \pm 0.36 a b$ & $1.37 \pm 18.96 c d$ & $1.60 \pm 0.416 a b c d$ & $1.14 \pm 5.47 d$ \\
\hline
\end{tabular}




\section{TABLE 4}

Effect of Plant Essential Oils at Different Levels on Fungi Inhibition (DAY FOUR)

\begin{tabular}{lrllc}
\hline TREATMENT & \multicolumn{1}{l}{$\mathbf{0}$} & $\mathbf{0 . 0 1}$ & $\mathbf{0 . 0 1}$ & $\mathbf{0 . 0 0 1}$ \\
\hline Neem & $2.56 \pm 51.2 a$ & $1.23 \pm 13.45$ & $1.11 \pm 0.08 b$ & $1.35 \pm 0.17 a b$ \\
Basil & $2.59 \pm 8.52 a$ & $2.14 \pm 6.85 a b$ & $1.86 \pm 0.15 a b$ & $1.92 \pm 1.920 .31 \mathrm{ab}$ \\
Ginger & $2.23 \pm 8.46 \mathrm{ab}$ & $1.56 \pm 18.86 \mathrm{ad}$ & $1.35 \pm 0,40 \mathrm{ab}$ & $1.56 \pm 11.03 \mathrm{ab}$ \\
\hline
\end{tabular}

\section{TABLE 5}

Effect of Plant Essential Oils at Different Levels on Fungi Inhibition (DAY FIVE)

\begin{tabular}{lllll}
\hline TREATMENT & $\mathbf{0}$ & $\mathbf{0 . 0 1}$ & $\mathbf{0 . 0 1}$ & $\mathbf{0 . 0 0 1}$ \\
\hline Neem & $2.73 \pm 140.29 a b$ & $1.80 \pm 13.63 b c$ & $1.96 \pm 20.1 b c$ & $2.0433 .10 a b c \pm$ \\
Basil & $2.39 \pm 17.97 a b c$ & $1.16 \pm 0.05 \mathrm{c}$ & $1.86 \pm 18.96 \mathrm{bc}$ & $1.90 \pm 7,43 \mathrm{bc}$ \\
Ginger & $3.33 \pm 0.04 a$ & $2.15 \pm 0.03 \mathrm{abc}$ & $2.41 \pm 11.49 a b c$ & $2.57 \pm 5.47 a b$ \\
\hline
\end{tabular}

TABLE 6

Effect of Plant Essential Oils at Different Levels on Fungi Inhibition (DAY SIX)

\begin{tabular}{lllll}
\hline TREATMENT & $\mathbf{0}$ & $\mathbf{0 . 0 1}$ & $\mathbf{0 . 0 1}$ & $\mathbf{0 . 0 0 1}$ \\
\hline Neem & $2.54 \pm 16.52 a b c$ & $1.87 \pm 35.5 b c$ & $1.95 \pm 0.03 a b c$ & $2.30 \pm 0.06 a b c$ \\
Basil & $2.87 \pm 17.97 \mathrm{abc}$ & $\pm 18.18 a b c$ & $2.02 \pm 0.02 a b c$ & $1.94 \pm 0.03 a b c$ \\
Ginger & $3.00 \pm 11.49 a$ & $1.48 \pm 4.85 c$ & $1.61 \pm 11.49 c$ & $1.62 \pm 0.02 c$ \\
\hline
\end{tabular}

\section{TABLE 7}

Effect of Plant Essential Oils at Different Levels on Fungi Inhibition (DAY SEVEN)

\begin{tabular}{llllc}
\hline TREATMENT & $\mathbf{0}$ & $\mathbf{0 . 0 1}$ & $\mathbf{0 . 0 1}$ & $\mathbf{0 . 0 0 1}$ \\
\hline Neem & $2.75 \pm 16.32 a$ & $2.67 \pm 11.03 a$ & $2.60 \pm 0.34 a$ & $2.76 \pm 51.2 a$ \\
Basil & $2.92 a \pm 8.36$ & $2.77 \pm 10.16 a$ & $2.59 \pm 043 a$ & $2.79 \pm 18.86 a$ \\
Ginger & $2.85 \pm 0.17 a$ & $2.17 \pm 0.31 a$ & $2.4 \pm 0.31$ & $2.48 \pm 4.85$ \\
\hline
\end{tabular}




\section{TABLE 8}

Effect of Plant Essential Oils at Different Levels on Fungi Inhibition (DAY EIGHT)

\begin{tabular}{lcccl}
\hline TREATMENT & \multicolumn{1}{l}{} & $\mathbf{0 . 0 1}$ & $\mathbf{0 . 0 1}$ & $\mathbf{0 . 0 0 1}$ \\
\hline Neem & $2.68 \pm 11.49 a b$ & $1.95 \pm 5.47 a b c$ & $2.09 \pm 0.03 a b c$ & $1.97 \pm 16.21 a b c$ \\
Basil & $2.74 \pm 18.18 a b$ & $1.54 \pm 0.05 b c$ & $1.83 \pm 11.52 a b c$ & $1.79 \pm 13.43 a b c$ \\
Ginger & $3.01 \pm 0.33 a$ & $1.36 \pm 4.32 c$ & $1.68 \pm 5.69 b c$ & $1.82 \pm 0.16 a b c$ \\
\hline
\end{tabular}

\section{TABLE 9}

Effect of Plant Essential Oils at Different Levels on Fungi Inhibition (DAY NINE)

\begin{tabular}{lcccc}
\hline TREATMENT & $\mathbf{0}$ & $\mathbf{0 . 0 1}$ & $\mathbf{0 . 0 1}$ & $\mathbf{0 . 0 0 1}$ \\
\hline Neem & $3.20 \pm 8.36 A$ & $2.29 \pm 6.27 a b$ & $2.31 \pm 0.16 b c$ & $2.75 \pm 16.96 \mathrm{abc}$ \\
Basil & $3.20 \pm 11.03 a$ & $3.01 \pm 0.005 a b$ & $2.54 \pm 4.42 \mathrm{abc}$ & $2.88 \pm 11.43 \mathrm{abc}$ \\
Ginger & $3.20 \pm 7.43$ & $2.24 \pm 0.39 c$ & $2.54 \pm 0.18 a b c$ & $3.13 \pm 0.08 a$ \\
\hline
\end{tabular}

TABLE 10

Effect of Plant Essential Oils at Different Levels on Fungi Inhibition (DAY TEN)

\begin{tabular}{lllll}
\hline TREATMENT & $\mathbf{0}$ & $\mathbf{0 . 0 1}$ & $\mathbf{0 . 0 1}$ & $\mathbf{0 . 0 0 1}$ \\
\hline Neem & $3.27 \pm 16.52 a$ & $2.60 \pm 49.4 a$ & $2.79 \pm 35.5 a$ & $2.80 \pm 13.99$ \\
Basil & $3.35 \pm 17.9 a$ & $3.18 \pm 13.99 \mathrm{a}$ & $3.18 \pm 18.8 \mathrm{a}$ & $3.14 \pm 0.06 a$ \\
Ginger & $2.68 \pm 11.49 \mathrm{a}$ & $1.35 \pm 0.006 b$ & $1.41 \pm 4.85 b$ & $1.58 \pm 0.23 b$ \\
\hline
\end{tabular}

